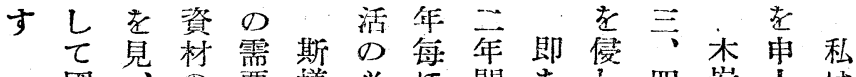
國、の要㥎必間ちし四炭上は 內爾騰をに需約に之つ萬は壮昨

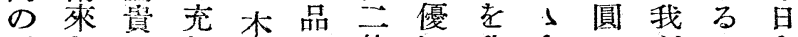
需年をし炭で倍に我あにがこま 要々促得僄历の五がり達家とで

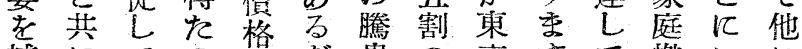

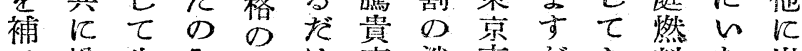
ひ增生み滕け率消市がお料た出

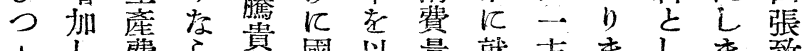

湠於小し賈ら貴國以量就方禾しま致

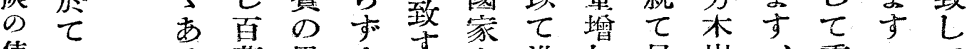

使注る萬異少与隻加見炭、重

用自次貫常許原乞ん老乃整要

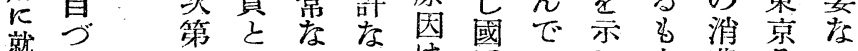

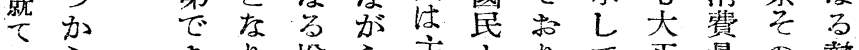

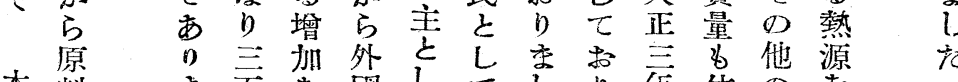

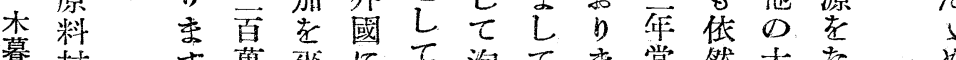

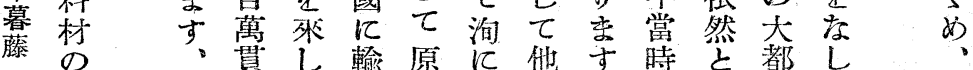

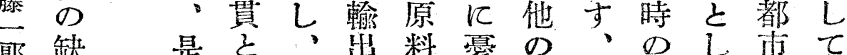
是之、出料憂の、のと市て 不

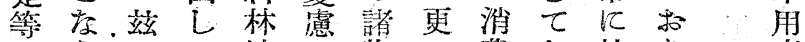

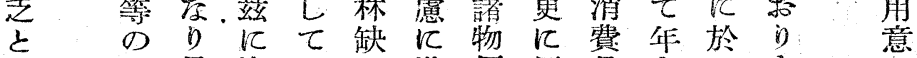

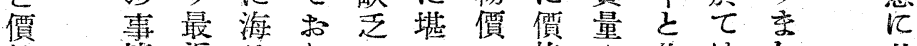

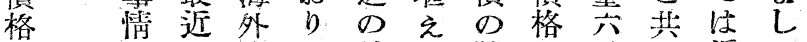

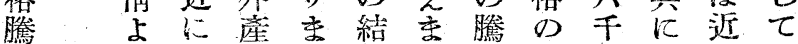

貴りりは本し果せ量方萬增年現

考年炭た它的率任貫加瓦在

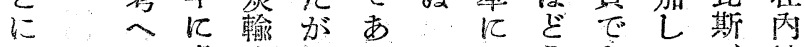

刺豆入彼己比 万市て。地

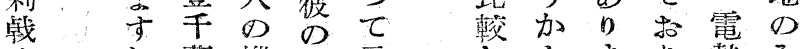

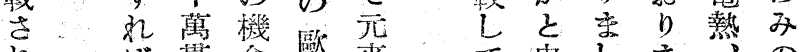

狆芯貫會弫來

乙 吾整妾州我

穱客輸與戰國

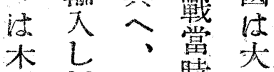

碎充炭近大照正

究炭近大需正

遂溜洁年要

万年年

视, 就南增、比

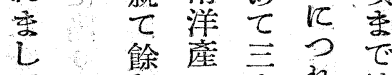

七:程の干机

三其 考 $\checkmark$ 五て國

最せ虫市市石使

岁ば唯油角

去十所沉材

指四謂就、料

嘍三华紊学見持

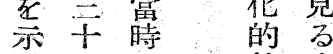

L 年

乙閒は

熱安合

数數妾

三合之葛原內

b 於千

娄占草

が量占

b 暮

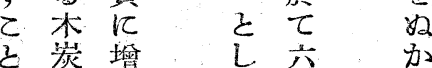

多於年

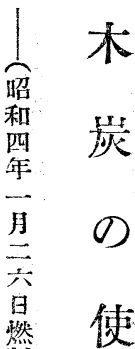

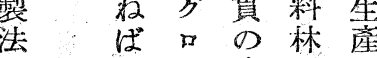

㤌價扣

学、支 $\infty$

種台ブ茄監杰

格兄。

狆䲲 僅

乙 億

芜萬思

藤

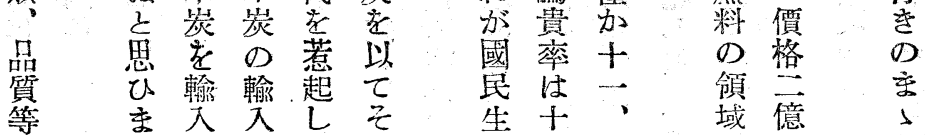

用

$\sqrt{6}$

就

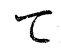




\section{月三作四和 昭}

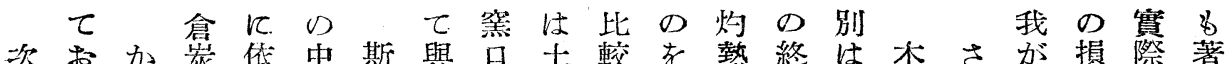

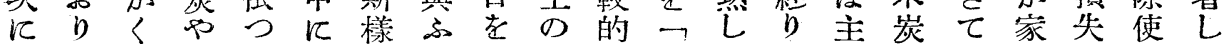

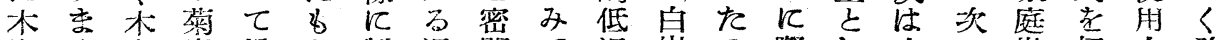

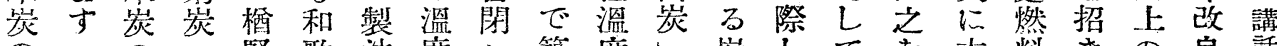
の の 堅 歌法度し築度し炭して老术料きの良話

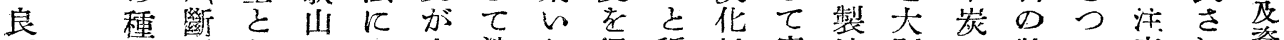

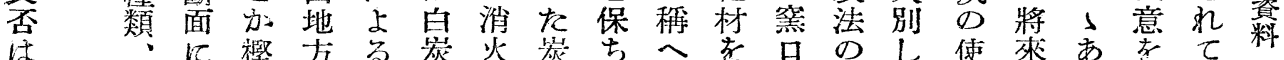

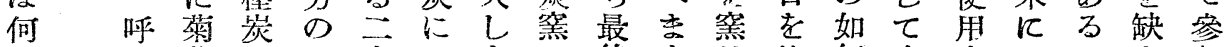

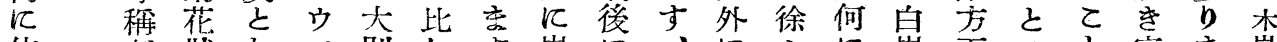

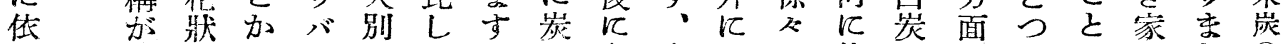

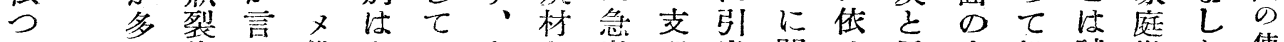
て 岐條う備市低之老激那出開る黑事恱誠燃た使 識複をた長る溫が詰にでし穵炭柄ばに料、用

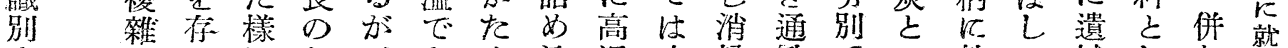

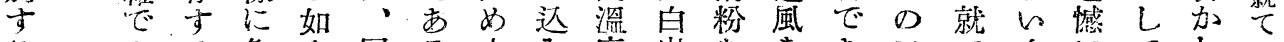

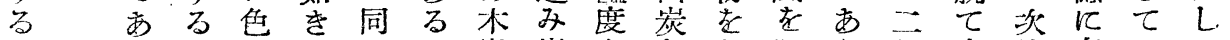

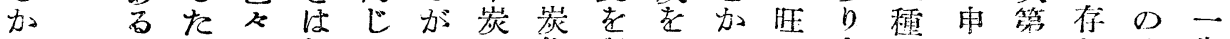

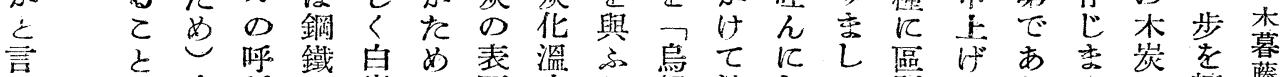

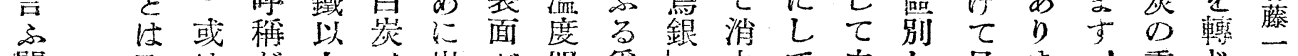

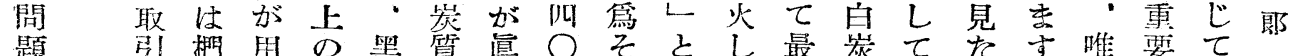

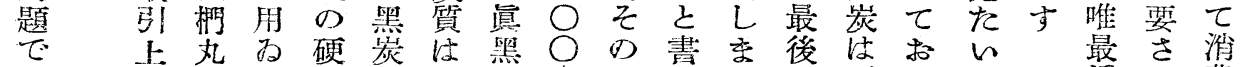

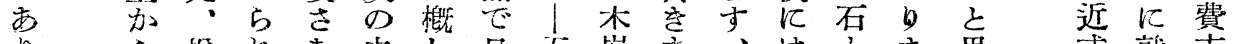

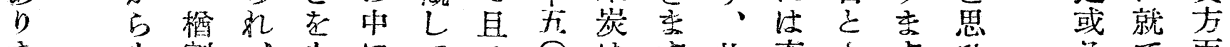

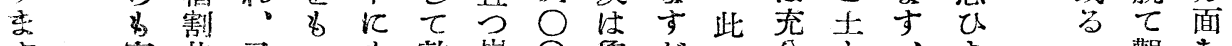

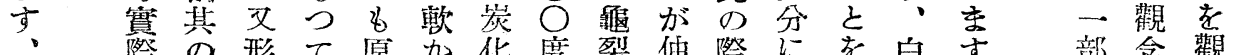

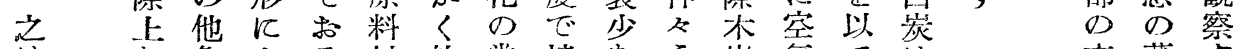
は加色上る材外常燒な5炭氣ては方薄等

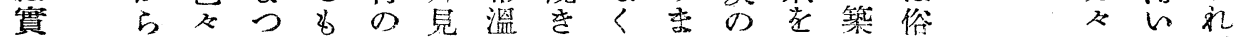

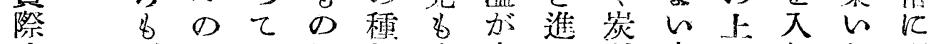

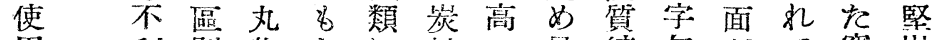
用利別物离汇材い最締句がて䈚炭

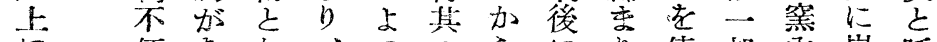
に便市出:

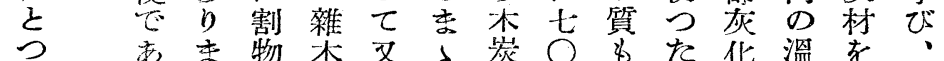

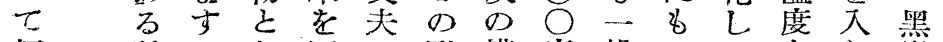
極所加原々形㮖度般のて在孷 め加的料の態斷加飞之白一炭は

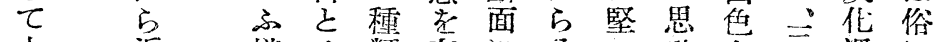

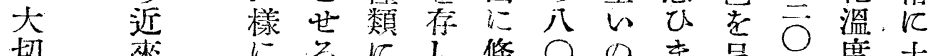

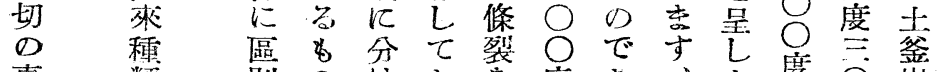
事類 別 D

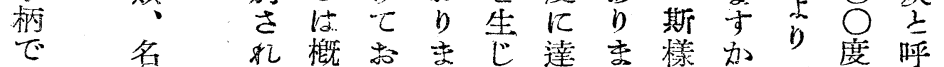

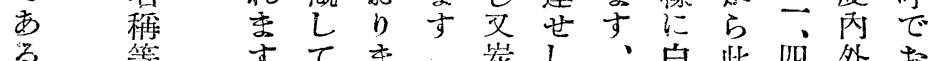

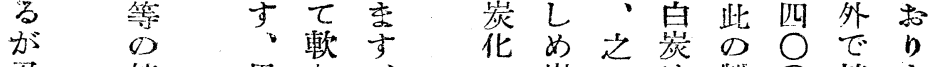
又統墨加、の炭飞製吕燒ま

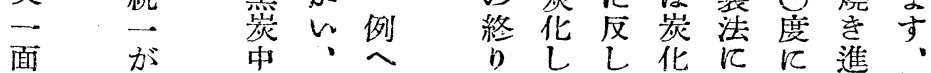

に圖に疗に終ての市高めて

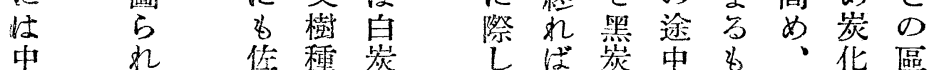

にボば

依た遺

$己$ 点

$\tau \sqrt{c}$

木自が

炭然 ら

の涺今

沙 費

費 。佮

經 濫 㾁

濟塤木

がに炭

叫陷に

ばり 對

况國方

蒙莎三

樣 的 理 三

飞解三

故 6

り 家 智

ま庭識

$L$ 的 $z$

た $儿$

乙

幕苦 


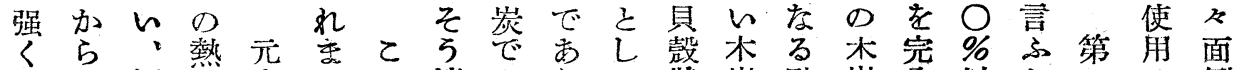

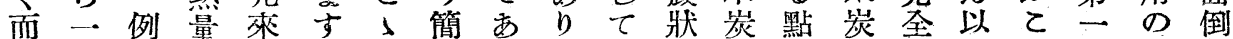
か度へで熱.で單り穿舉の程にのに上との目の

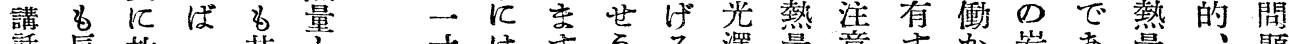

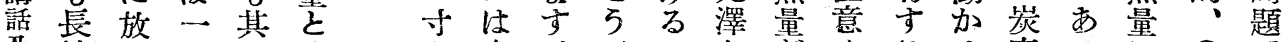

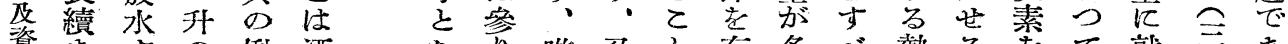

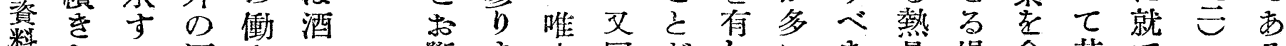

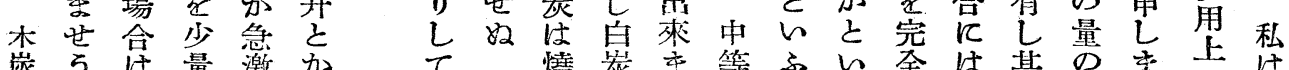

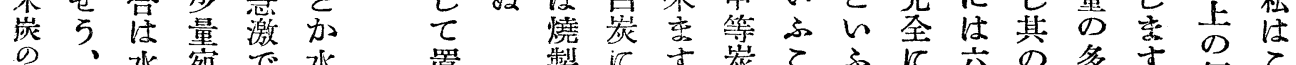

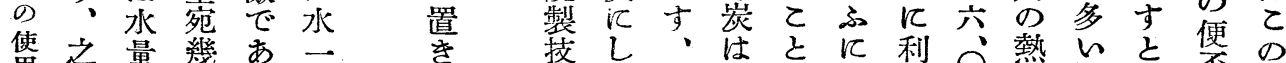

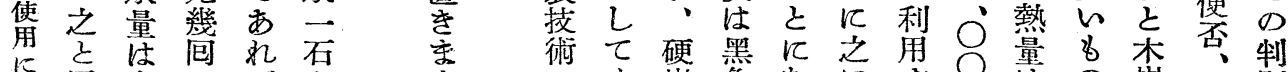

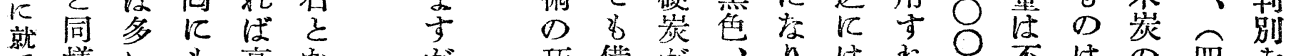

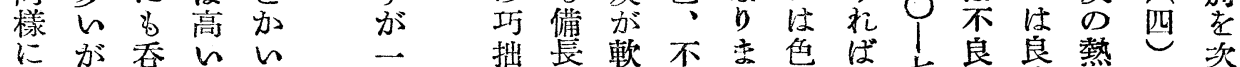

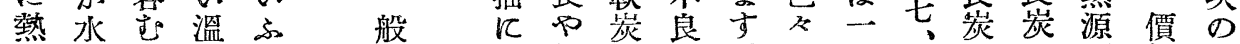

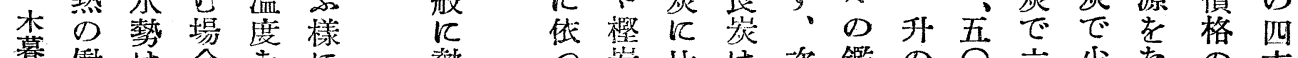

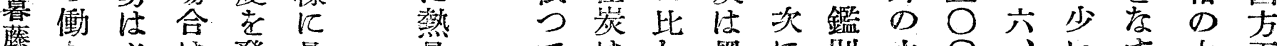

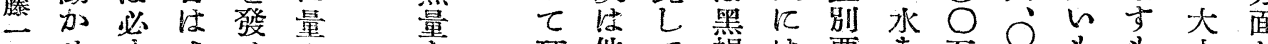

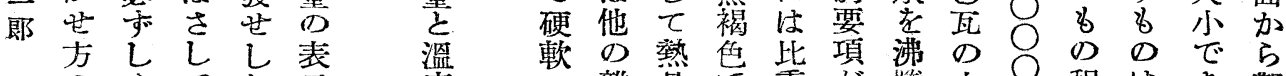

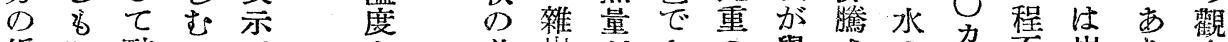

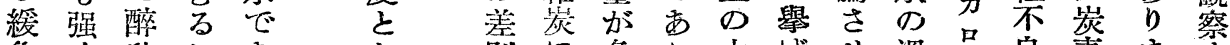

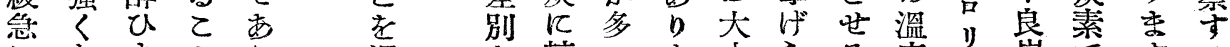

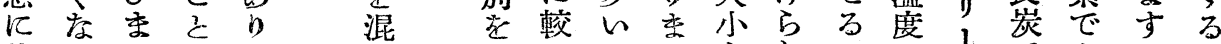

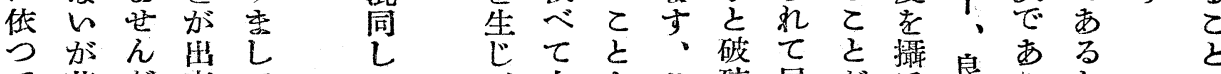

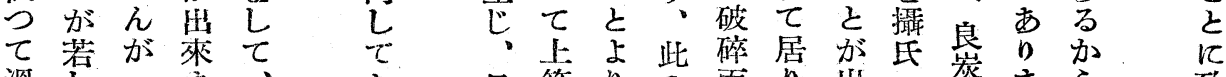

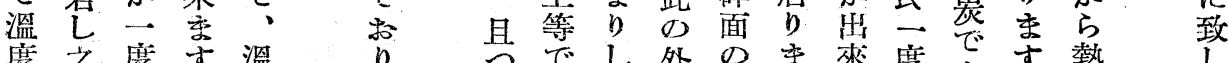

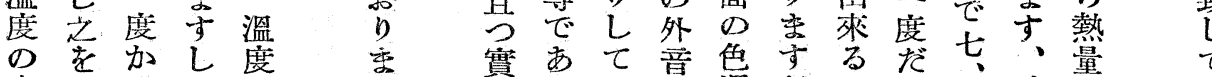

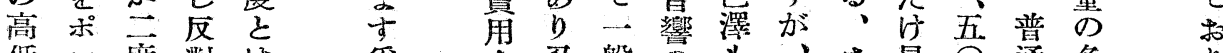

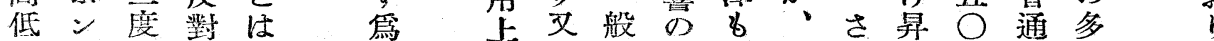
生で 吞多基吕

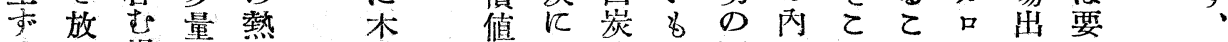

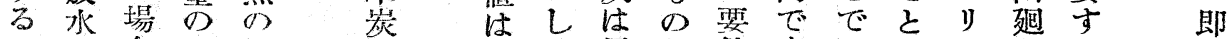
口合熱働: の 必て黑朗件素此が

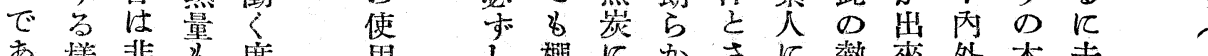

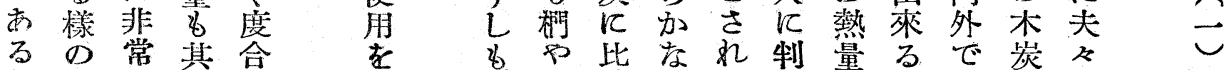

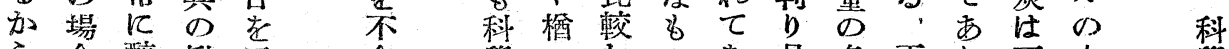

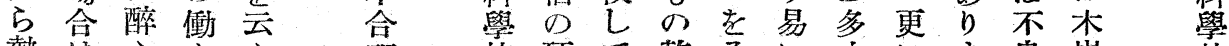
熱々心をふ理的硬て乾るん少に良炭的

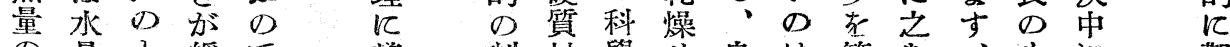

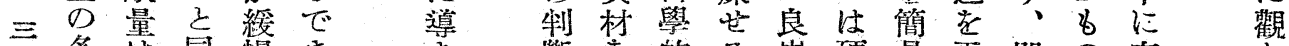

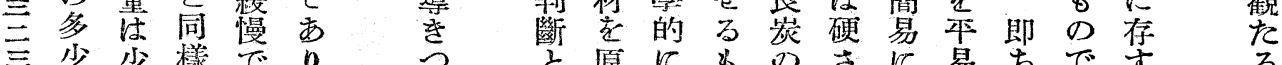

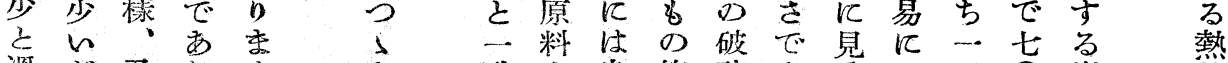

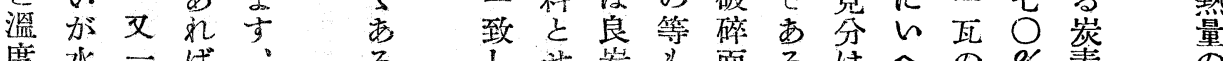

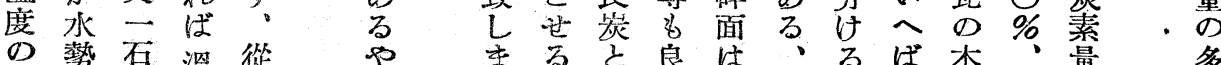

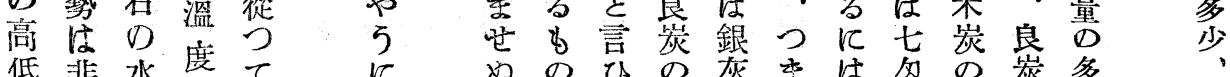

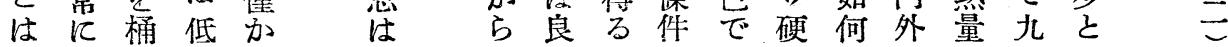




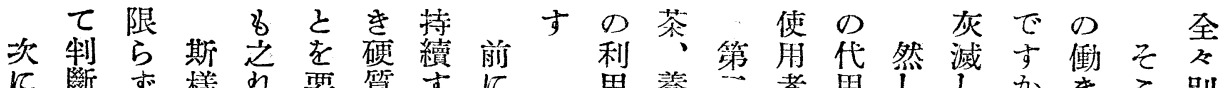

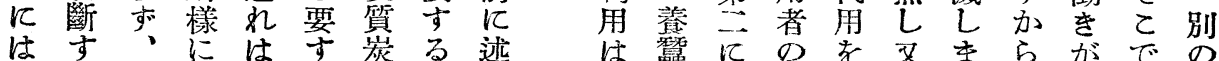

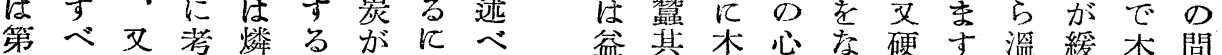

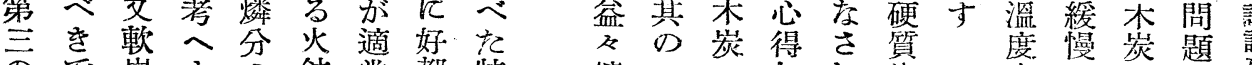

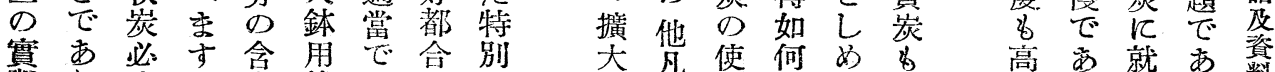

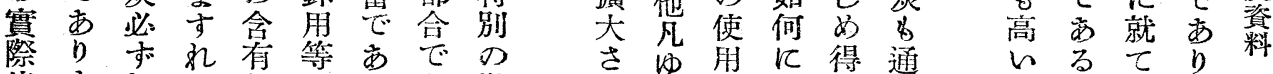

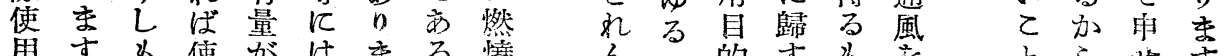

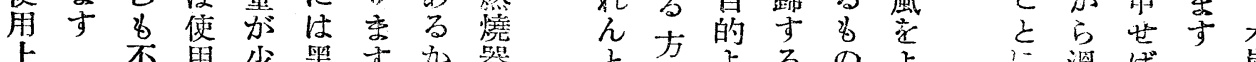
上否角少墨与、加器 便䈐目的分養占

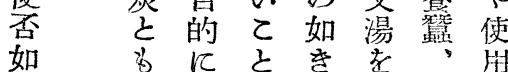
何斷文颙わ空方

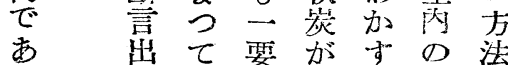

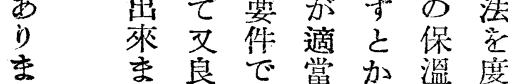

す、主良は黨其溫度

木如不方要他㹕置

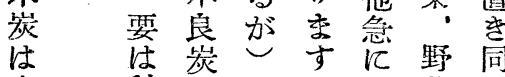

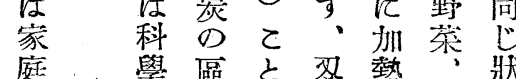

燃的別济物等態

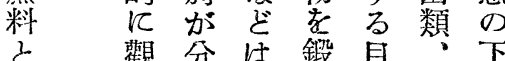

己 憼分は䤵目和海に

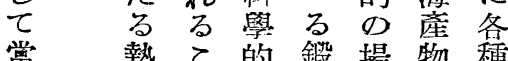

當熱 $乙$ 的鍛場物種

時量之治合等

D $反$ 叶屋只 0 木

必合なつ炭或針炭

需理りた店燥を

品角守角は少晋的曼角

あ法为之加屋す

b老方云术其る

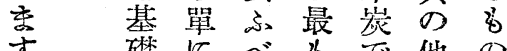

す 礎㳂

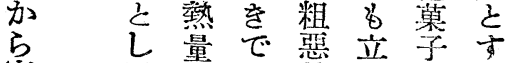

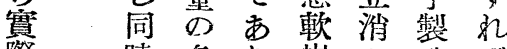

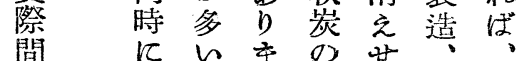

題使硬世松蓑料硬

之 角岑 5 炭火理炭

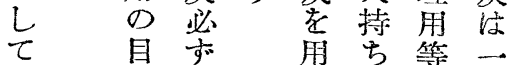

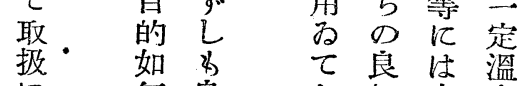

几何良: 吉好白度

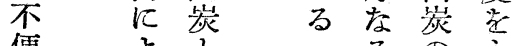

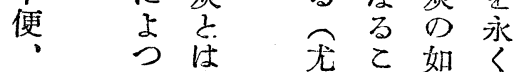

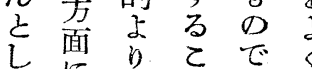

て, 使 白市す

出集せ

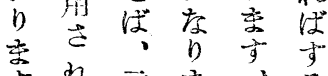

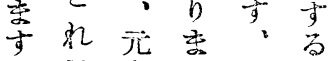

、最來せ

今近本

日不炭

は炭の

ट 赎

寺 毕用

間 斯 涂

に高

が發は

西生今

b穖

世考京

次案 $b$

加廣

万沈

等 自㐫

D動 D

事車京

於 罚

省 カ

ま ソ 家

七 妾

力 H

渵壮

度度 硬

b杜㷋

言低泣

、望

唯 然の

前る 含

战軟䭪

多炭壮

量は多

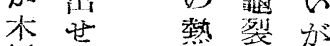

炭己量文术

のる 合る 徐裂炭

理之等两

Lン这

極角煮

く等

䑹元探

的或 暖

用在资

的

にに部

利出湓富に

途 船 馀

にI

就 啋 䤵

用來 費

す空 隐

ひ寺氣少

換 L, 為の存

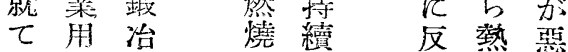

の動、器艺

み方乾 具 $L$

舟之嚛

れ 軟 溫 觸 炭

ば炭 度面質

会 \& ब が が

上L用葓 て

げて翋硬

持 庴 緻

熱通、續く文密

の孛堪通あ

經扣之氣方

濟減学に方

的すが都ら

用梳後合䆙

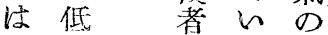

壮所 流

之加通

L D

て 短き㗢

战 熱 


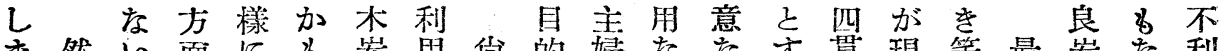

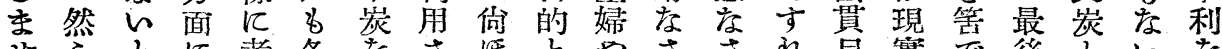
せ 講 其へ方古庭筈る

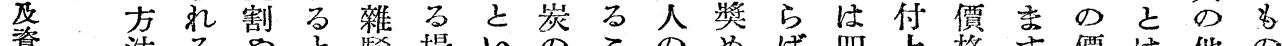
窲法る

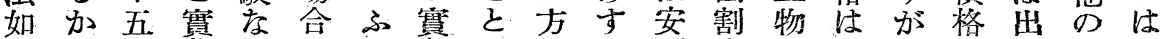

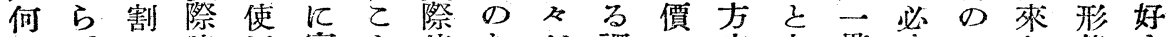
木とでの使角賽之使なが譯の安中貫ずてな態至

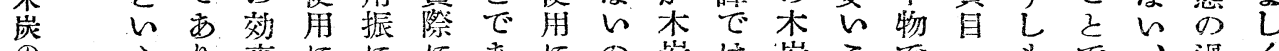
使 己

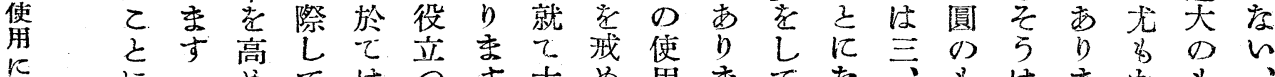
僦在: 方て

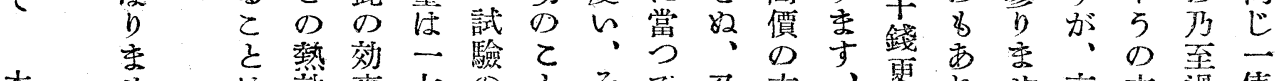

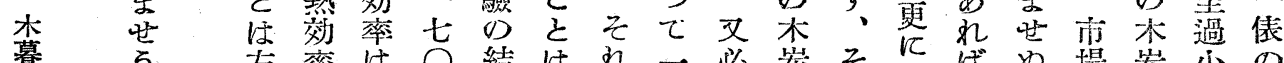

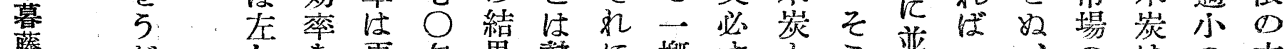

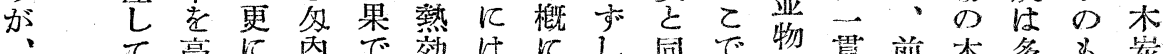

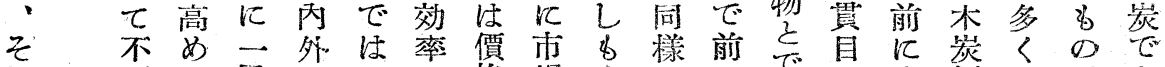

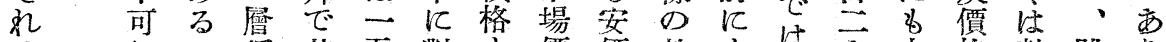
は一能乙低其五對と價價效为在干市格熱跳り 要でとくの「すい格の果申分錢上は量ね㑐

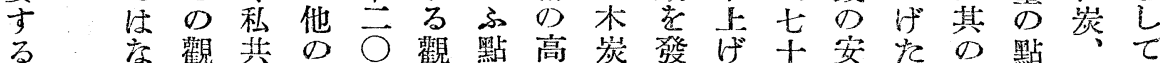

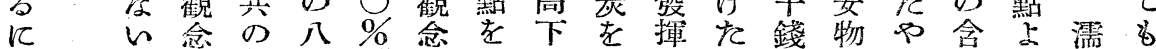

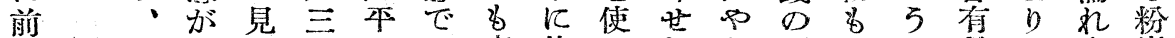

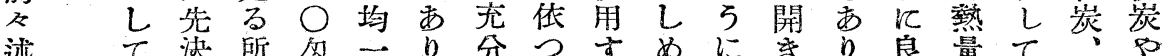

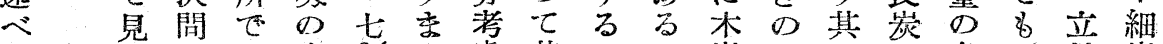

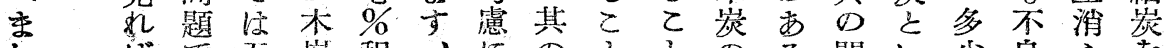

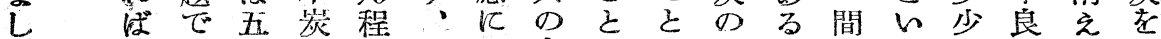

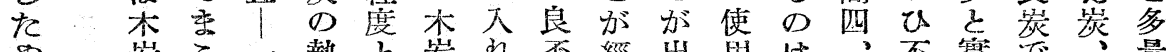

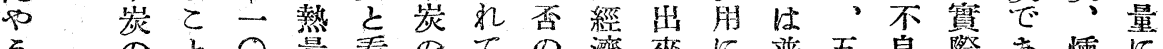

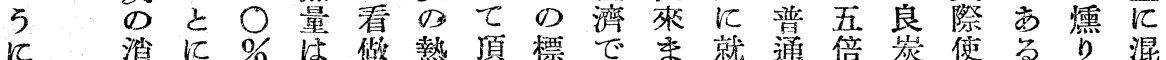

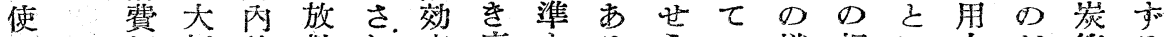

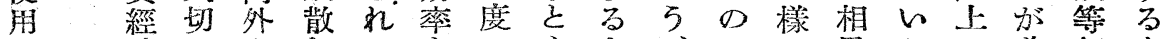

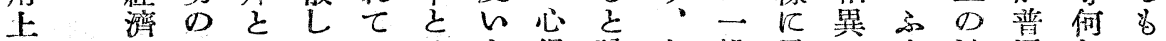

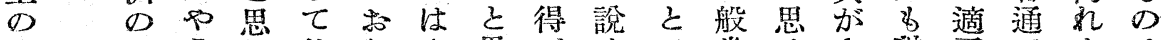

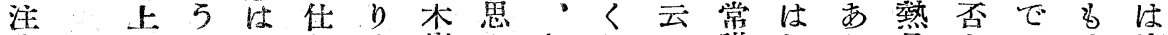

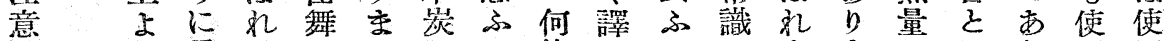

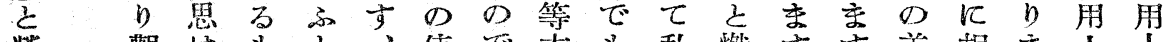

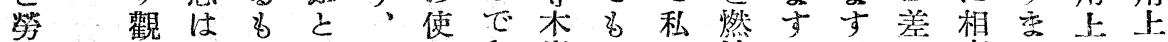

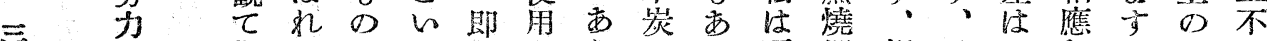

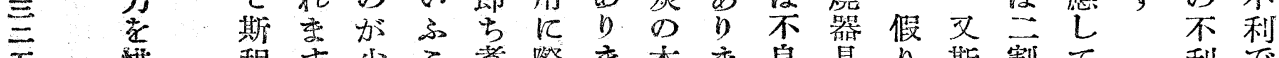

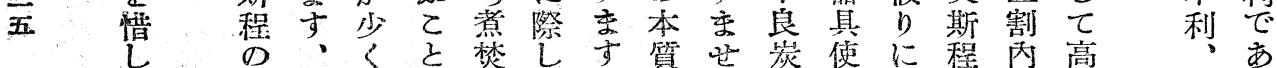

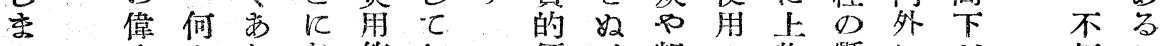

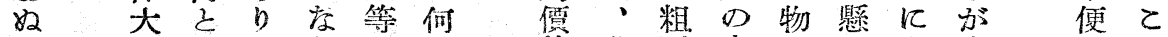

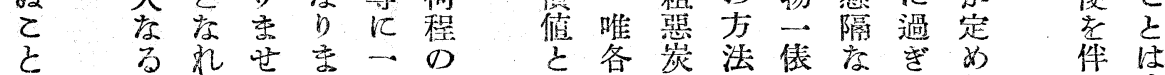

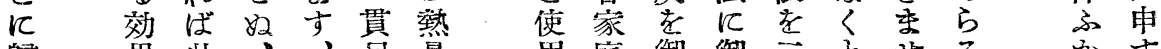

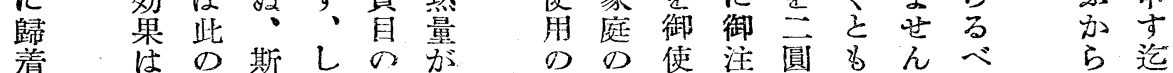




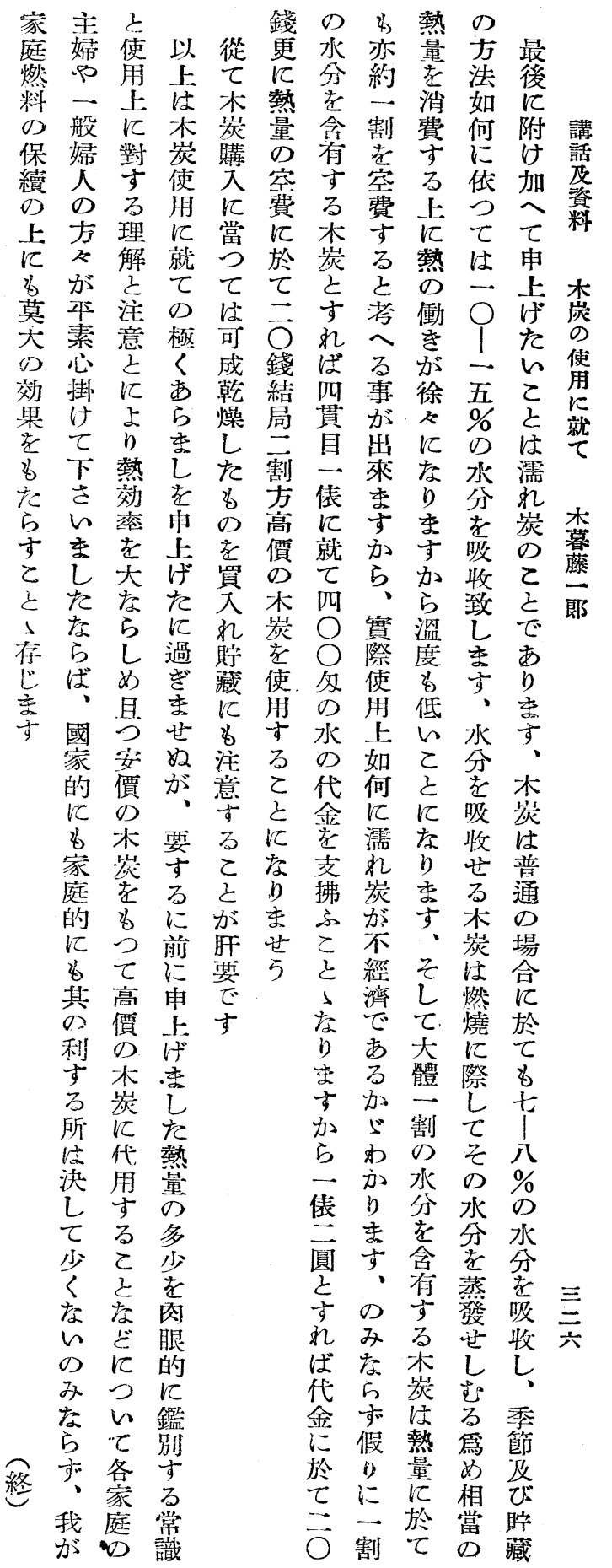

